\title{
A New Natural Quaternary Indole Alkaloid Isolated from Tabernaemontana laeta Mart. (Apocynaceae)
}

\author{
Walter L. B. Medeiros ${ }^{a}$, Ivo José C. Vieira ${ }^{b}$, Leda Mathias ${ }^{b}$, Raimundo Braz-Filho ${ }^{b *}$ and Jan Schripsema ${ }^{b}$ \\ ${ }^{a}$ Departamento de Química, Universidade Federal Rural do Rio de Janeiro, 23851-970, Seropédica - RJ, Brazil \\ ${ }^{\mathrm{b}}$ Setor de Química de Produtos Naturais, Universidade Estadual do Norte Fluminense, 28015-620, \\ Campos dos Goytacazes - RJ, Brazil
}

\begin{abstract}
Um novo alcalóide quaternário natural, $\mathrm{N}_{\mathrm{b}}$-metilvoachalotina (1), três alcalóides indólicos diméricos, conodurina (2), voacamina (3) e tabernamina (4), e os três alcalóides monoméricos $19 S$-heyneanina (5), coronaridina (6) e voacangina (7) foram isolados da casca das raízes de Tabernaemontana laeta. Os triterpenos conhecidos 3- $O$-acetil- $\alpha$-amirina, 3- $O$-acetil- $\beta$-amirina, 3- $O$-acetil-lupeol e 3- $O$-acetiltaraxasterol e os fitoesteróides $\beta$-sitosterol e seu derivado $3-O-\beta$-Dglicopiranosídeo foram também identificados. As estruturas dos compostos foram elucidadas com base na análise de dados espectroscópicos.
\end{abstract}

A new natural quaternary alkaloid, $\mathrm{N}_{\mathrm{b}}$-methylvoachalotine (1), was obtained from the root bark of Tabernaemontana laeta together with three dimeric indole alkaloids, conodurine (2), voacamine (3) and tabernamine (4), and the monomeric indole alkaloids $19 S$-heyneanine (5), coronaridine (6) and voacangine (7). The known triterpenes $\alpha$-amyrin acetate, $\beta$-amyrin acetate, lupeol acetate and taraxasterol acetate and the phytosterol $\beta$-sitosterol and its $3-O-\beta$-D-glucoside were also identified. The structures of the compounds were elucidated based on spectroscopic studies.

Keywords: Tabernaemontana laeta, Apocynaceae, indole-alkaloids, triterpenes

\section{Introduction}

Indole alkaloids exhibit numerous biological activities (such as anti-tumor, anti-microbial, anti-hypertensive and central nervous system stimulant ${ }^{1}$ ). They can be found in plants of the Apocynaceae, Rubiaceae, and Loganiaceae families $^{1,2}$.

Among the Apocynaceae, the genus Tabernaemontana is especially rich in indole alkaloids. They are useful chemical markers of the genus, and also have a great value for the classification of the individual species within the genus $^{3}$. The classification of individual species only on the basis of morphological characters has been difficult, leading to numerous synonyms ${ }^{4}$. The species Tabernaemontana laeta Mart. has the homotypic synonym Peschiera laeta (Mart.) Miers, and the heterotypic synonyms T. laeta var. pubiflora Muell. Arg., T. laeta var. minor Muell. Arg., T.

\footnotetext{
* e-mail: braz@uenf.br
}

laeta var. densa Muell. Arg., T. spixiana Mart. ex Muell. Arg. and T. breviflora Muell. Arg. ${ }^{4}$. Some previous phytochemical studies have been published under the name Peschiera laeta Mart.5,6.

As part of our continuing interest in the phytochemical investigation of Tabernaemontana species occurring in Brazil, we decided to study T. laeta, a native species of the Atlantic forest in Southeastern Brazil. Popularly known as "esperta" or "guarana", this species is generally considered poisonous. In a recent paper, we reported the complete ${ }^{1} \mathrm{H}$ and ${ }^{13} \mathrm{C}$ chemical shift assignments of the dimeric indole alkaloids conodurine (2) and voacamine (3); both isolated from its methanolic extracts ${ }^{7}$.

In the present study, we report the phytochemical analysis of the crude extracts of $T$. laeta, including the isolation of the new alkaloid $\mathrm{N}_{\mathrm{b}}$-methylvoachalotine (1).

\section{Results and Discussion}

Chromatographic purification of $T$. laeta root bark hexane and methanol extracts yielded triterpenes and 
phytosterols common in plants, including other Tabernaemontana species ${ }^{8}$. The triterpene acetates were obtained as a mixture of $\alpha$-amyrin acetate, $\beta$-amyrin acetate, lupeol acetate and taraxasterol acetate. They were identified by comparison of the ${ }^{1} \mathrm{H}$ and ${ }^{13} \mathrm{C}$ NMR spectral data with literature values ${ }^{9}$. The phytosterol $\beta$-sitosterol, isolated from the hexane extract, and its 3-O- $\beta$-D-glucopyranosyl derivative, isolated from the methanol extract, were also identified by comparison with published ${ }^{1} \mathrm{H}$ and ${ }^{13} \mathrm{C}$ NMR spectral data, including the data of the peracetyl derivative of 3-O- $\beta$-D-glucopyranosyl $-\beta$-sitosterol ${ }^{10}$.

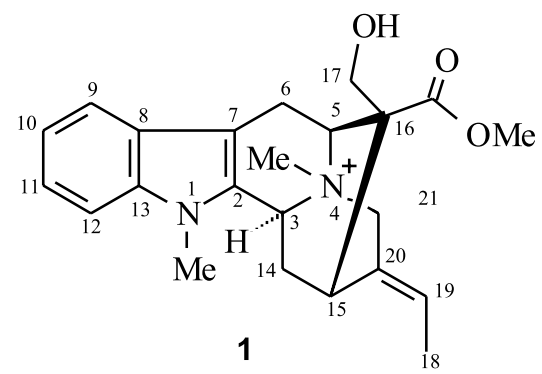

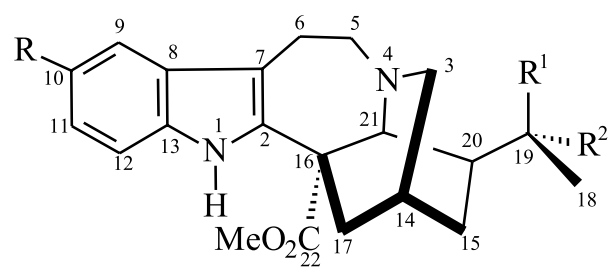

$5 \mathrm{R}=\mathrm{R}^{2}=\mathrm{H}, \mathrm{R}^{1}=\mathrm{OH}(19 S)$

$6 \quad \mathrm{R}=\mathrm{R}^{1}=\mathrm{R}^{2}=\mathrm{H}$

$7 \mathrm{R}=\mathrm{MeO}, \mathrm{R}^{1}=\mathrm{R}^{2}=\mathrm{H}$

$8 \quad \mathrm{R}=\mathrm{R}^{1}=\mathrm{H}, \mathrm{R}^{2}=\mathrm{OH}(19 R)$

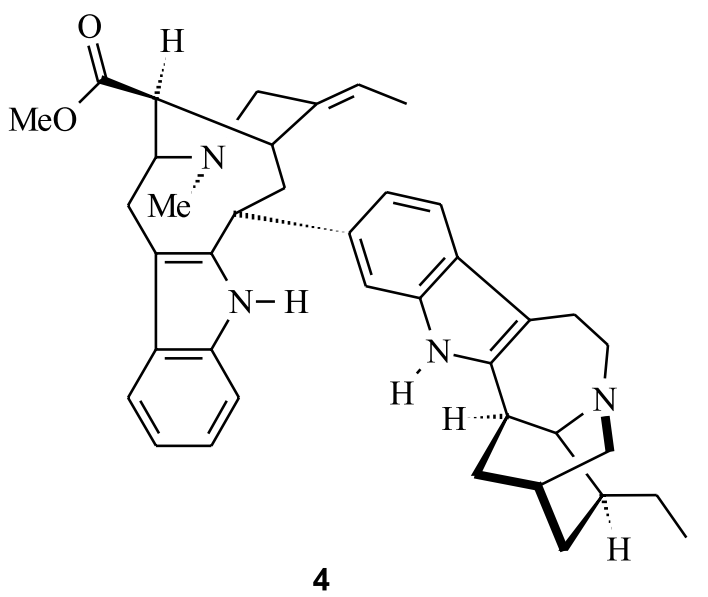

In addition to the dimeric alkaloids conodurine (2) and voacamine (3), previously reported ${ }^{7}$, other structurally related alkaloids were obtained during a detailed phytochemical analysis of the methanol extract. The known indole alkaloids tabernamine (4) ${ }^{11}, 19 S$-heyneanine $(\mathbf{5}$, vide infra), coronaridine $(6)^{12}$ and voacangine $(7)^{13}$ were identified on the basis of ${ }^{1} \mathrm{H}$ and ${ }^{13} \mathrm{C}$ NMR spectral data, including homonuclear ${ }^{1} \mathrm{H}-{ }^{1} \mathrm{H}-\mathrm{COSY}$ and heteronuclear ${ }^{1} \mathrm{H}-$ ${ }^{13} \mathrm{C}$ 2D shift-correlated NMR experiments ${ }^{14}$.

The $19 S$ configuration shown in $\mathbf{5}$ was clearly established by comparison of the NMR chemical shifts

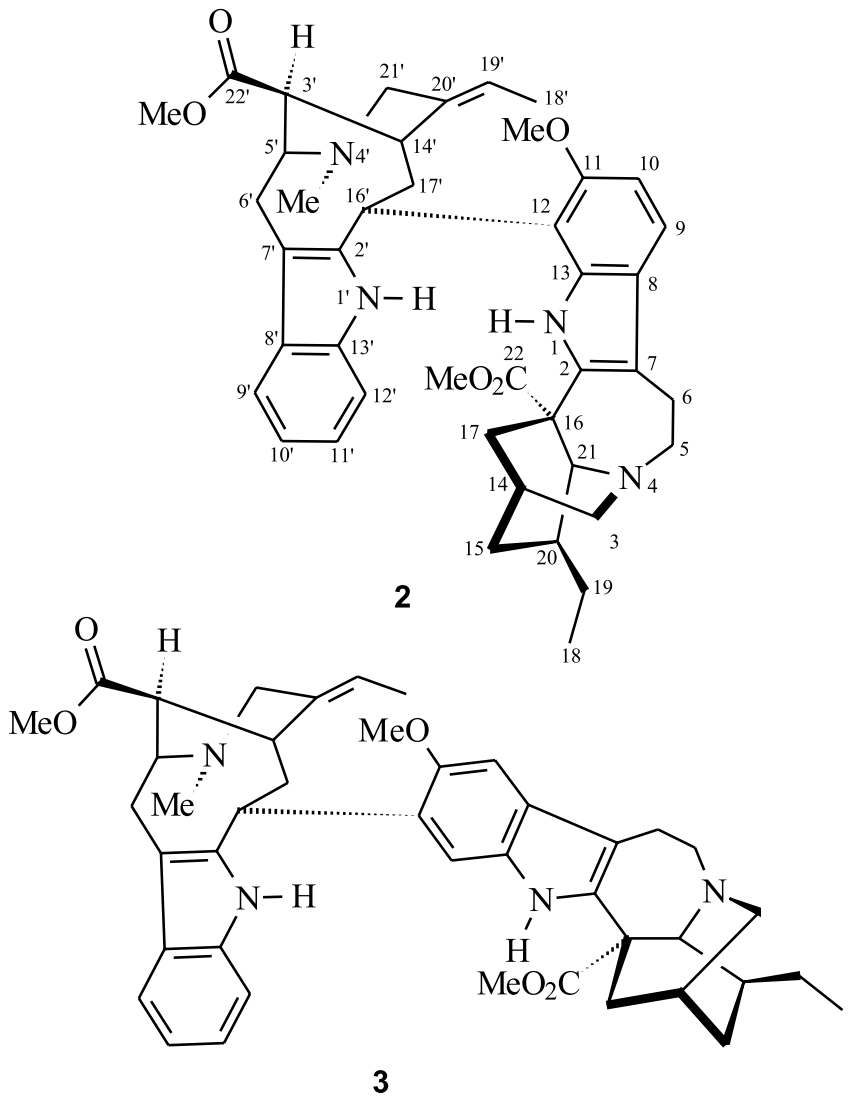

3

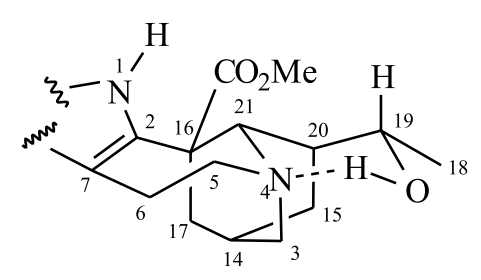

5a

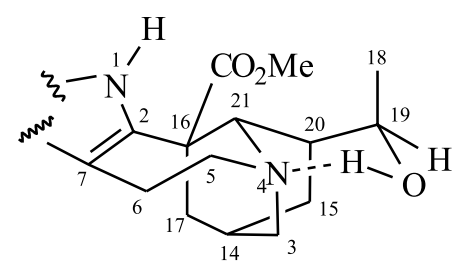


obtained with those reported for heyneanine (5) and its epimer, (19R)-epiheyneanine (8). Due to hydrogen bonding between the hydroxyl group at C-19 and the nearby nitrogen the 1-hydroxyethyl moiety has a rigid conformation (see partial structures 5a and 8a), leading to considerable chemical shift differences. In the ${ }^{1} \mathrm{H}$ NMR spectrum especially the chemical shifts of the $3 \mathrm{H}-18$ and $\mathrm{H}-19$ hydrogens show large differences. Values of $\delta_{\mathrm{H}} 1.11$ $(3 \mathrm{H}-18)$ and $4.12(\mathrm{H}-19)$ for 5 and $\delta_{\mathrm{H}} 1.27(3 \mathrm{H}-18)$ and 3.92 (H-19) for 8 have been reported (both in $\left.\mathrm{CDCl}_{3}\right)^{15}$. For the isolated compound 5 values of $\delta_{\mathrm{H}} 1.11(3 \mathrm{H}-18)$ and 4.16 (H-19) were measured. The chemical shifts of the carbon atoms $\mathrm{CH}_{2}-15\left(\delta_{\mathrm{C}} 22.9\right), \mathrm{CH}-19\left(\delta_{\mathrm{C}} 72.3\right)$ and $\mathrm{CH}-21\left(\delta_{\mathrm{C}} 59.7\right)$ reported for $\mathbf{5}^{13}$ are significantly different when compared with those reported for $8: \delta_{\mathrm{C}} 28.60\left(\mathrm{CH}_{2}-\right.$ 15), $70.70(\mathrm{CH}-19)$ and $54.30(\mathrm{CH}-21)^{16,17}$. The values measured pointed to an identical configuration for the chiral carbon $\mathrm{C}-19$ of the isolated product and heyneanine (5) $\left[\delta_{\mathrm{C}} 22.93\left(\mathrm{CH}_{2}-15\right), 71.34(\mathrm{CH}-19)\right.$ and $\left.59.78(\mathrm{CH}-21)\right]$.
By the $\gamma$-effect of the methyl group $\left(\mathrm{CH}_{3}-18\right) \mathrm{CH}_{2}-15$ $\left(\Delta \delta_{\mathrm{C}}=5.67 \mathrm{ppm}\right)$ in 5 and $\mathrm{CH}-21\left(\Delta \delta_{\mathrm{C}}=5.40 \mathrm{ppm}\right)$ in $\mathbf{8}$ are shielded. In the absence of this effect these carbon atoms appear deshielded [5: $\delta_{\mathrm{C}} 59.87(\mathrm{CH}-21) ; \mathbf{8}: \delta_{\mathrm{C}} 28.60\left(\mathrm{CH}_{2}-\right.$ 15)].

The new indole alkaloid $\mathbf{1}$ was isolated from the methanol extract. The ESMS showed a molecular ion at $m / z, 381$ daltons $\left([\mathrm{M}]^{+}\right)$, in agreement with the molecular formula $\mathrm{C}_{23} \mathrm{H}_{29} \mathrm{~N}_{2} \mathrm{O}_{3}$ and with ${ }^{1} \mathrm{H}$ and ${ }^{13} \mathrm{C}$ NMR spectral data. This alkaloid was nearly insoluble in chloroform and its NMR spectra were therefore obtained in DMSO- $d_{6}$. Carbon-13 NMR experiments (HBBD and DEPT) revealed the presence of four methyl groups, four methylenes $\left(\mathrm{sp}^{3}\right)$, eight methines (three $\mathrm{sp}^{3}$ and five $\mathrm{sp}^{2}$ ) and seven quaternary carbon atoms (one $\mathrm{sp}^{3}$ and six $\mathrm{sp}^{2}$ ). The ${ }^{1} \mathrm{H}-{ }^{1} \mathrm{H}-\mathrm{COSY}$, HMQC and HMBC experiments established geminal and vicinal hydrogen interactions as well as direct $\left({ }^{1} J_{\mathrm{CH}}\right)$ and two and three bond correlations between carbon and hydrogen atoms in the structure (Table 1). These data

Table 1. ${ }^{1} \mathrm{H}(400 \mathrm{MHz})$ and ${ }^{13} \mathrm{C}(100 \mathrm{MHz})$ NMR for $\mathrm{N}_{\mathrm{b}}$-methylvoachalotine (1), including results obtained by heteronuclear 2D shift-correlated HMQC $\left({ }^{1} J_{\mathrm{CH}}\right)$ and $\mathrm{HMBC}\left({ }^{\mathrm{n}} J_{\mathrm{CH}}, \mathrm{n}=2\right.$ and 3$)$, in DMSO- $d_{6}$ as solvent and residual DMSO- $d_{6}$ used as internal reference $\left(\delta_{\mathrm{H}} 2.50\right.$ and $\left.\delta_{\mathrm{C}} 39.50\right)$. Chemical shifts $(\delta$, $\mathrm{ppm})$ and coupling constants $(\mathrm{J}, \mathrm{Hz}$, in parenthesis).*

\begin{tabular}{|c|c|c|c|c|}
\hline & \multicolumn{2}{|r|}{${ }^{1} \mathrm{H}-{ }^{-13} \mathrm{C}-\mathrm{HMQC}-{ }^{-1} J_{\mathrm{CH}}$} & \multicolumn{2}{|c|}{${ }^{1} \mathrm{H}-{ }^{13} \mathrm{C}-\mathrm{HMBC}-{ }^{\mathrm{n}} J_{\mathrm{CH}}$} \\
\hline & $\delta_{\mathrm{C}}$ & $\delta_{\mathrm{H}}$ & ${ }^{2} J_{\mathrm{CH}}$ & ${ }^{3} J_{\mathrm{CH}}$ \\
\hline \multicolumn{5}{|l|}{$\mathbf{C}$} \\
\hline 2 & 132.16 & - & $\mathrm{H}-3$ & 2H-6, H-14a, MeN-1 \\
\hline 7 & 101.34 & - & $2 \mathrm{H}-6$ & H-5, H-9 \\
\hline 8 & 124.43 & - & & H-6a, H-10, H-12 \\
\hline 13 & 137.55 & - & & H-9, H-11, MeN-1 \\
\hline 16 & 54.70 & - & $\mathrm{H}-5,2 \mathrm{H}-17$ & $\mathrm{HO}-17,2 \mathrm{H}-6, \mathrm{H}-14 \mathrm{a}$ \\
\hline 20 & 127.71 & - & $2 \mathrm{H}-21$ & $3 \mathrm{H}-18$ \\
\hline 22 & 172.65 & - & & $\mathrm{H}-5,2 \mathrm{H}-17, \mathrm{MeO}-22$ \\
\hline \multicolumn{5}{|l|}{$\mathbf{C H}$} \\
\hline 3 & 57.02 & $5.19($ br d, 11.0) & & $\mathrm{H}-5, \mathrm{H}-21 \mathrm{~b}, \mathrm{MeN}-4$ \\
\hline 5 & 63.16 & $4.19(\mathrm{~d}, 6.4)$ & $2 \mathrm{H}-6$ & 2H-17, MeN-4 \\
\hline 9 & 118.22 & $7.55(\mathrm{~d}, 7.7)$ & & H-11 \\
\hline 10 & 119.47 & $7.10(\mathrm{dd}, 7.7,7.1)$ & & $\mathrm{H}-12$ \\
\hline 11 & 122.15 & $7.23(\mathrm{dd}, 7.1,8.2)$ & & H-9 \\
\hline 12 & 109.82 & $7.51(\mathrm{~d}, 8.2)$ & & $\mathrm{H}-10$ \\
\hline 15 & 29.11 & 3.22 & & H-17a, H-19 \\
\hline 19 & 118.22 & $5.47(\mathrm{q}, 6.8)$ & $3 \mathrm{H}-18$ & \\
\hline \multicolumn{5}{|l|}{$\mathrm{CH}_{2}$} \\
\hline 6 & 18.61 & $3.70,3.21$ & H-5 & \\
\hline 14 & 27.52 & $2.39(\mathrm{ddd}, 13.7,11.0,2.2), 2.10(\mathrm{ddd}, 13.7,3.5,3.5)$ & & \\
\hline 17 & 62.31 & $3.53(\mathrm{dd}, 10.8,3.6), 3.40(\mathrm{dd}, 10.8,4.2)$ & HO-17 & H-5 \\
\hline 21 & 63.61 & $4.38(\mathrm{dt}, 16.4,2.3), 4.31(\mathrm{dt}, 16.4,2.0)$ & & H-19 \\
\hline \multicolumn{5}{|l|}{$\mathbf{C H}_{2}$} \\
\hline 18 & 12.34 & $1.62(\mathrm{~d}, 6.8)$ & H-19 & \\
\hline MeN-1 & 29.11 & $3.65(\mathrm{~s})$ & & \\
\hline $\mathrm{MeN}-4$ & 48.70 & $3.16(\mathrm{~s})$ & & \\
\hline $\mathrm{MeO}-22$ & 52.41 & $3.67(\mathrm{~s})$ & & \\
\hline HO-17 & - & $5.26(\mathrm{dd}, 4.2,3.6)$ & & \\
\hline
\end{tabular}

*Number of hydrogens bound to carbon atoms deduced by comparative analysis of HBBD- and DEPT- ${ }^{13} \mathrm{C}$ NMR spectra. Chemical shifts and coupling constants $(J)$ obtained of $1 \mathrm{D}{ }^{1} \mathrm{H}$ NMR spectrum. Superimposed ${ }^{1} \mathrm{H}$ signals are described without multiplicity and chemical shifts deduced by HMQC, $\mathrm{HMBC}$ and ${ }^{1} \mathrm{H}-{ }^{1} \mathrm{H}-\mathrm{COSY}$ spectra. 
revealed that $\mathbf{1}$ is closely related to voachalotine (vide infra), differing by the presence of an additional methyl group. The presence of the indole nucleus was clearly indicated by the ${ }^{1} \mathrm{H}$ and ${ }^{13} \mathrm{C}$ aromatic signals (Table 1 ). Typically the ${ }^{1} \mathrm{H}$ NMR revealed three singlet signals corresponding to methyl groups at $\delta_{\mathrm{H}} 3.67,3.65$ and 3.16. Through analysis of the HMBC spectrum these signals were assigned by corresponding cross-peaks, due to heteronuclear spin-spin coupling via three $\left({ }^{3} J_{\mathrm{CH}}\right)$ bonds, to a carbomethoxy function and two methyl groups linked to the indole $\mathrm{N}-1$ and N-4 (aliphatic $\left.\mathrm{N}_{\mathrm{b}}\right)$, respectively: a) C-22 $\left(\delta_{\mathrm{C}} 172.65\right)$ with $\mathrm{MeO}-$ $22\left(\delta_{\mathrm{H}} 3.67\right), \mathrm{H}-5\left(\delta_{\mathrm{H}} 4.19\right)$ and $2 \mathrm{H}-17\left(\delta_{\mathrm{H}} 3.53\right.$ and 3.40$)$; b) MeN-1 $\left(\delta_{\mathrm{H}} 3.65\right)$ with both $\mathrm{C}-2\left(\delta_{\mathrm{C}} 132.16\right)$ and $\mathrm{C}-13$ $\left(\delta_{\mathrm{C}} 137.55\right)$ and $\left.\mathrm{c}\right) \mathrm{MeN}-4\left(\delta_{\mathrm{H}} 3.16\right)$ with both $\mathrm{CH}-5\left(\delta_{\mathrm{C}}\right.$ 63.16) and $\mathrm{CH}-3\left(\delta_{\mathrm{C}} 57.02\right)$. The complete analysis of this HMBC spectrum in combination with additional NMR spectral data also allowed the identification of a skeleton as that of the indole alkaloid voachalotine ${ }^{18}$ and the total ${ }^{1} \mathrm{H}$ and ${ }^{13} \mathrm{C}$ chemical shift assignments, as summarized in Table 1. The stereochemistry of the chiral carbon atom C16 shown in $\mathbf{1}$ was clearly indicated by the chemical shift of the signal at $\delta_{\mathrm{H}} 3.67$ corresponding to the hydrogen of the MeO-22 (carbomethoxy group). In its epimer this signal should appear at about $\delta_{\mathrm{H}} 2.50$, as observed in $\mathbf{2}$ and $\mathbf{3}$ by singlet signals of the MeO-22' at $\delta_{\mathrm{H}} 2.51$ and 2.46, respectively ${ }^{7}$. Thus, the new quaternary indole alkaloid isolated from Tabernaemontana laeta was characterized as $\mathrm{N}_{\mathrm{b}}$-methylvoachalotine (1), a new natural product. Although it has been synthesized from voachalotine in a previous study ${ }^{18}$, only the ${ }^{13} \mathrm{C}$ NMR data of the iodide salt were reported.

In accordance with the revision published by Leeuwenberg $^{4}$, the alkaloid series isolated in this study from T. laeta are closely related to those previously reported from Peschiera laeta: geissoschizol, affinine, akuammidine, normacusine $\mathrm{B}$, vobasine, conodurine and voacamine $\mathrm{e}^{5,6}$. The similarity of the alkaloids found in this work in comparison with those from two other Brazilian Tabernaemontana species is remarkable. From $T$. solanifolia were reported the following alkaloids: isovoacangine, isovoacristine, coronaridine, voacangine, voacangine hydroxyindolenine, heyneanine, voacamine, voachalotine and 12-methoxy-Nb-methylvoachalotine [reported under the name Peschiera campestris (Rizz.) Rizz. by Gower, Pereira and Marsaioli ${ }^{19}$ ], while from $T$. hystrix were reported the following alkaloids: 12-methoxy$\mathrm{N}_{\mathrm{b}}$-methylvoachalotine, 12-methoxy- $\mathrm{N}_{\mathrm{b}}$-methylvoachalotine ethyl ester and fuchsiaefoline (reported under the name Peschiera fuchsiaefolia by Braga and Reis ${ }^{18}$ ). This similarity might point to a close taxonomic relationship of these recognized species.

\section{Experimental}

\section{General}

${ }^{1} \mathrm{H}$ NMR and ${ }^{13} \mathrm{C}$ NMR spectra were obtained with Bruker DRX spectrometers operating at 400 and $600 \mathrm{MHz}$ and 100 and $150 \mathrm{MHz}$, respectively, in $\mathrm{CDCl}_{3}$ or DMSO$d_{6}$, using the residual solvent signals as internal standard (Table 1).

\section{Plant material}

The root bark of Tabernaemontana laeta Mart. was collected in July 1997 at Bom Jesus do Itabapoana, Rio de Janeiro State, Brazil, and identified by Dr. A. J. M. Leeuwenberg of the Agricultural University of Wageningen, The Netherlands. A voucher specimen (WAG) is deposited at the herbarium of the Agricultural University of Wageningen, Netherlands.

\section{Extraction and isolation}

Dried and powdered root bark $(1.06 \mathrm{~kg})$ from $T$. laeta Mart. was extracted at room temperature using hexane and methanol, furnishing, after solvent evaporation, crude hexane (33.4 g) and methanol (120.0 g) extracts, respectively.

The hexane extract was purified by silica gel chromatography, with a gradient of EtOAc in hexane to give four fractions. The second fraction supplied large amounts $(28.0 \mathrm{~g})$ of a product, which by recrystallization in hexane, furnished a mixture of the four triterpenes, $\alpha$ amyrin acetate, $\beta$-amyrin acetate, lupeol acetate and taraxasterol acetate. The third fraction yielded, after recrystallization, $\beta$-sitosterol $(220.0 \mathrm{mg})$. The fourth fraction yielded, after column chromatography with the same system, the alkaloid voacangine ${ }^{13}(7,15.0 \mathrm{mg})$.

The methanol extract was redissolved in $\mathrm{MeOH} / \mathrm{H}_{2} \mathrm{O}$ (3:1) and extracted with $\mathrm{CHCl}_{3}$. The $\mathrm{CHCl}_{3}$ layer was evaporated and further partitioned between $\mathrm{MeOH}$ and hexane (1:1). After another extraction with hexane, the hydromethanolic fraction was extracted with EtOAc. The methanol phase yielded $55.0 \mathrm{~g}$ upon evaporation, the hexane phase $22.4 \mathrm{~g}$ and the EtOAc phase $2.0 \mathrm{~g}$.

The EtOAc extract was chromatographed on a silica gel column with a gradient of EtOAc in hexane supplying four fractions. Preparative TLC of fractions 1 and 2 (hexane:EtOAc 5\%) supplied the alkaloids 5 (146.0 mg) and 6 (19.0 $\mathrm{mg})$, respectively.

$30.0 \mathrm{~g}$ of the methanol extract was chromatographed on a silica gel column and eluted with a gradient of EtOAc 
in hexane, yielding four fractions; fraction $1(1.3 \mathrm{~g})$ presented additional amounts of $\mathbf{5}$; fraction $2(9.8 \mathrm{~g})$ was rechromatographed with a gradient of $\mathrm{CH}_{2} \mathrm{Cl}_{2}$ in hexane, supplying additional amounts of $\mathbf{6}(0.6 \mathrm{~g})$ and 7 (340.0 $\mathrm{mg})$; fraction $3(10.5 \mathrm{~g}$ ) was rechromatographed in the same way, supplying the alkaloids 2 (130.0 $\mathrm{mg}$ ) and $\mathbf{3}$ (315.0 $\mathrm{mg})$. Fraction $4(7.3 \mathrm{~g})$ was rechromatographed with a gradient of $\mathrm{MeOH}$ in $\mathrm{CH}_{2} \mathrm{Cl}_{2}$ furnishing 12 fractions, of which, fractions 3-4 $(520.0 \mathrm{mg})$ furnished the alkaloid 4 $(53.0 \mathrm{mg})$ after rechromatography with a gradient of $\mathrm{MeOH}$ in $\mathrm{CH}_{2} \mathrm{Cl}_{2}$, followed by column chromatography over Sephadex LH-20 with methanol. Fractions 6-7 (1.2 g) yielded a crystalline substance, characterized as $\mathrm{N}_{\mathrm{b}}$ methylvoachalotine (1, 38.0 mg). Fractions 10-12 (3.6 g) supplied an amorphous powder; this material $(100.0 \mathrm{mg})$ was acetylated and the acetylated product was identified as 3-O- $\beta$-D-glucosyl $-\beta$-sitosterol tetraacetate.

The five alkaloids 2-6, as well as triterpenes, $\beta$-sitosterol and 3-O- $\beta$-D-glucopyranosyl- $\beta$-sitosterol tetraacetate were identified by the analysis of the ${ }^{1} \mathrm{H}$ and ${ }^{13} \mathrm{C}$ NMR spectra and comparison with literature values ${ }^{7-13,15-17}$.

$N_{b}$-methylvoachalotine (1)

White crystalline solid, mp $259-260{ }^{\circ} \mathrm{C}(\mathrm{MeOH})$; $[\alpha]^{25}{ }_{\mathrm{D}}-21.3^{\circ}$ (DMSO, $c$ 6.3); IR $v_{\max } / \mathrm{cm}^{-1} 3298(\mathrm{OH}), 1736$ $(\mathrm{C}=\mathrm{O}), 1616,1591,743$ (aromatic ring) $(\mathrm{KBr}) ; \mathrm{UV} \lambda_{\text {max }}$ ' $\mathrm{nm}\left(\mathrm{CH}_{3} \mathrm{OH}\right) 223(\varepsilon$ 42566), 282 ( $\varepsilon$ 6287); ESMS (positive ion mode) $\mathrm{m} / \mathrm{z} 381\left([\mathrm{M}+\mathrm{H}]^{+}\right.$, base peak), $367([\mathrm{M}+\mathrm{H}-$ $\left.\left.\mathrm{CH}_{3}\right]^{+}\right) ;{ }^{1} \mathrm{H}$ NMR and ${ }^{13} \mathrm{C}$ NMR Table 1 .

\section{Acknowledgements}

The authors are grateful to Programa de Apoio ao Desenvolvimento Científico e Tecnológico (PADCT)/ Financiadora de Estudos e Projetos (FINEP) and Fundação Estadual do Norte Fluminense (FENORTE) for grants, to $\mathrm{CNPq}$ for a research fellowship. Dr. Jane Thomas-Oates and Dr. Abass Bundu from the University of Manchester are acknowledged for the ESMS spectra. The "Centro Nacional de Ressonância Magnética Nuclear", Departamento de Bioquímica Médica, UFRJ, is gratefully acknowledged for access to the NMR facilities.

\section{References}

1. Verpoorte, R. In Alkaloids: Biochemistry, Ecology and Medicinal Applications; Roberts, M. F. \& Wink, M., Ed.; Plenum Press; New York, 1998, pp 397-433.
2. Bruneton, J. Pharmacognosy, Phytochemistry, Medicinal Plants. Intercept Limited - Lavoisier, Andover UK, 1995, 826.

3. Van Beek, T. A.; Verpoorte, R.; Svendsen, A. B.; Leeuwenberg, A. J. M.; Bisset, N. G. J. Ethnopharmacol. 1984, 10, 1.

4. Leeuwenberg, A. J. M. A Revision of Tabernaemontana. Vol. 2. The New World Species and Stemmadenia. Royal Botanic Gardens, Kew, UK, 1994.

5. Jahodar, L.; Voticky, Z.; Cava, M.P. Phytochemistry 1974. $13,2880$.

6. Voticky, Z.; Jahodar, L.; Cava, M. P. Collect. Czech. Chem. Commun. 1977, 42, 1403.

7. Medeiros, W. L. B.; Vieira, I. J. C.; Mathias, L.; BrazFilho, R.; Leal, K. Z.; Rodrigues-Filho, E.; Schripsema, J. Magn. Reson. Chem. 1999, 37, 676.

8. Schripsema, J.; Hermans-Lokkerbol, A.; Van der Heijden, R.; Verpoorte, R.; Baerheim Svendsen, A. J. Nat. Prod. 1986. 49, 733.

9. Ahmad, V. U.; Atta-ur-Rahman. Handbook of Natural Products Data. Vol. 2. Pentacyclic Triterpenoids; Elsevier; Amsterdam, 1994, p. 136, 784, 786, 1157.

10. Chaurasia, N.; Wichtl, M. J. Nat. Prod. 1987, 50, 881.

11. Kan, C.; Henriques, A.; Jasor, Y.; Moretti, C.; Husson, H. P. J. Nat. Prod. 1984, 47, 487.

12. Kan, C.; Kan, S. K.; Husson, H. P.; Lounasmaa, M. J. Nat. Prod. 1981, 41, 72.

13. Atta-ur-Rahman; Fatima, T.; Mehrun-Nisa; Ijaz, S.; Crank, G.; Wasti, S. Planta Med. 1987, 53, 57.

14. Claridge, T. D. W. High-Resolution NMR Techniques in Organic Chemistry; Pergamon; Amsterdam, 1999.

15. Matos, F. J. A.; Braz-Filho, R.; Gottlieb, O. R.; Machado, F. W. L.; Madruga, M. I. L. M. Phytochemistry 1976, 15, 551.

16. Lemos, T. L. G.; Andrade, C. H. S.; Guimarães, A. M.; Wolter-Filho, W.; Braz-Filho, R. J. Braz. Chem. Soc. 1996, 7, 123.

17. Wenkert, E.; Cochran, D. W.; Gottlieb, H. E.; Hagaman, E. W.; Braz-Filho, R.; Matos, F. J. A.; Madruga, M. I. L. M. Helv. Chim. Acta 1976, 59, 2437.

18. Braga, R. M.; Reis, F. de A. M. Phytochemistry 1987, 26, 833.

19. Gower, A. E.; Pereira, B. da S.; Marsaioli, A. J. Phytochemistry 1986, 25, 2908.

Received: November 14, 2000 Published on the web: May 16, 2001 